\title{
A STUDY OF LONG BEAN VEGETABLE MARKETING (VignaSinesis L) IN AMBULU DISTRICT, JEMBER REGENCY
}

\author{
Syamsul Hadi ${ }^{* 1}$, and Evita Soliha Hani ${ }^{* *}$ \\ *) Agribusiness Study Program, Universitas Muhammadiyah Jember, Indonesia \\ Jl. Karimata No. 49 Jember, Indonesia \\ **) Agribusiness Study Program, Universitas Jember, Indonesia \\ Jl. Kalimantan No.37 Jember, Indonesia
}

\begin{abstract}
Long bean vegetable farming in Ambulu Subdistrict, Jember Regency has enormous potentials, indicated by the high demand for this vegetable. However, the price of long beans in Jember Regency at the retail level is too high and may cause high marketing margins. The objectives of this study were: 1) to determine the performance of the long bean marketing channel pattern, 2) to analyze the value of the long bean marketing margin, and 3) to analyze the elasticity of long bean price transmission. This research was conducted from March to October 2019, employing the descriptive method with survey techniques and snowballing sampling. In order to achieve the research objectives, each of the approaches used descriptive analysis, farmer's share (marketing efficiency), and price transmission elasticity. The results revealed that 1) the long bean marketing channel is formed by two channel patterns, namely two-level and one-level channels, 2) the twolevel channel pattern has a marketing margin of Rp. 3,383, - per $\mathrm{kg}$, and the one-level channel pattern has a marketing margin of IDR 1,500 per kg, and 3) the established marketing channel pattern generally has a price transmission elasticity of $\eta=1.17(\eta>1)$ and the form of the market structure leads to Oligopoly.
\end{abstract}

Keywords: long bean, performance of marketing channel patterns, marketing margins, price transmission elasticity, market structure

\begin{abstract}
Abstrak: Usaha tani sayuran kacang panjang di Kecamatan Ambulu Kabupaten Jember memiliki potensi yang sangat besar yang ditunjukkan oleh permintaan akan sayuran tersebut cenderung tinggi. Namun demikian harga kacang panjang di Kabupaten Jember pada tingkat pengecer terlampau tinggi dan berimplikasi pada tingginya margin pemasaran. Tujuan dari penelitian ini adalah: 1) Mengetahui keragaan pola saluran pemasaran kacang panjang yang terbentuk, 2) Menganalisis nilai margin pemasaran kacang panjang, dan 3) Menganalisis elastisitas transmisi harga panjang. Penelitian ini telah dilakukan pada bulan Agustus sampai dengan Desember 2019. Metode penelitian yang digunakan adalah metode deskriptif dengan teknik survei dan snowballing sampling. Guna mencapai tujuan penelitian, maka masing-masing pendekatannya digunakan analisis deskriptif, farmer's share (efisiensi pemasaran), dan elastisitas transmisi harga. Hasil penelitian mengungkapkan bahwa 1) Polasaluran pemasaran kacang panjang yang terbentuk dua pola saluran yaitu saluran dua tingkat, dan satu tingkat, 2) Pola saluran pemasaran dua tingkat memiliki margin pemasaran sebesar Rp 3.383,- per $\mathrm{kg}$, dan pola saluran pemasaran satu tingkat memiliki margin pemasaran sebesar $R p 1.500$ per $\mathrm{kg}$, dan 3) Pola saluran pemasaran yang terbangun secara umum memiliki elastisitas transmisi harga sebesar Et $=1.17$ (Et $>1)$ dan bentuk struktur pasar mengarah kepada Oligopoli.
\end{abstract}

Kata kunci: kacang panjang; pola saluran pemasaran, margin pemasaran, elastisitas transmisi harga, struktur pasar

\footnotetext{
${ }^{1}$ Corresponding author:

Email: syamsul.hadi@unmuhjember.ac.id
} 


\section{INTRODUCTION}

Long bean (Vignasinensis L.), on the one hand, is one of the annual shrub plants that are widely consumed by Indonesians, both as vegetables and vegetables in an effort to improve community nutrition as a source of vitamin A, vitamin B, vitamin $\mathrm{C}$, and minerals. Moreover, long bean seeds contain a lot of protein, fat and carbohydrates (Rahayu, 2007). On the other hand, long bean farming (VignaSinesis L.) has good economic prospects for small-scale farmers. The long bean vegetable market (VignaSinesis L.) is very promising and the market demand is mostly high making it easier for farmers to market long bean products easily and can be developed long bean with simple techniques and can be consumed by all circles (Anto, 2013).

The past few years development of long bean vegetable marketing has made it a promising marketing sector. According to the Indonesian Food Security Monitoring Bulletin (2017) that in 2016, fruit and vegetable consumption in Indonesia is less than half the recommended consumption. In addition, the marketing potential of long beans is also predicted because based on data that the productivity of long beans nationally has only reached around 395,524 tons. While the number of long bean consumption in 2014 reached $2,83 \mathrm{~kg} / \mathrm{capita} /$ year and in 2015 it reached $3.337 \mathrm{~kg} /$ capita/year, an increase from the previous year, so the production of long beans needs to be increased (BPS, 2016 in Wati, 2018) .
Furthermore, the above phenomenon is supported by the 2016 data of vegetable consumption in urban areas was slightly higher than that in rural areas in the same year, as shown in Figure 1. However, before 2015 there was a different trend where fruit and vegetable consumption in urban areas was lower than in rural. Analysis of national-level consumption trends for the last five years also shows the same thing: fruit and vegetable consumption in urban areas increased by 1.8 percent while in rural areas decreased by 10.7 percent. Fruit consumption tends to be higher in urban areas while vegetable consumption is higher in rural areas in Indonesia (Indonesian Food Security Monitoring Bulletin, 2017).

In line with the aforementioned potential in Indonesia, Jemberas one of the regencies in East Java Province is gifted with a very good agro-climate support. Aside from being a food granary in East Java, it is also very potential for the development of horticultural crops, especially vegetables. Commercially traded vegetable commodities in Jember Regency include: cabbage, petsay/mustard greens, tomatoes, chilies, eggplants, string beans, spinach, cucumbers, kale, watermelons, melons, cantaloupe, beans and onions (Department of Agriculture, Food Crops, 2007 in Maspur and Jamil, 2008). The condition of the development of long beans in Jember Regency is in line with the national condition, that it also has experienced a fluctuating trend as shown in Figure 2.

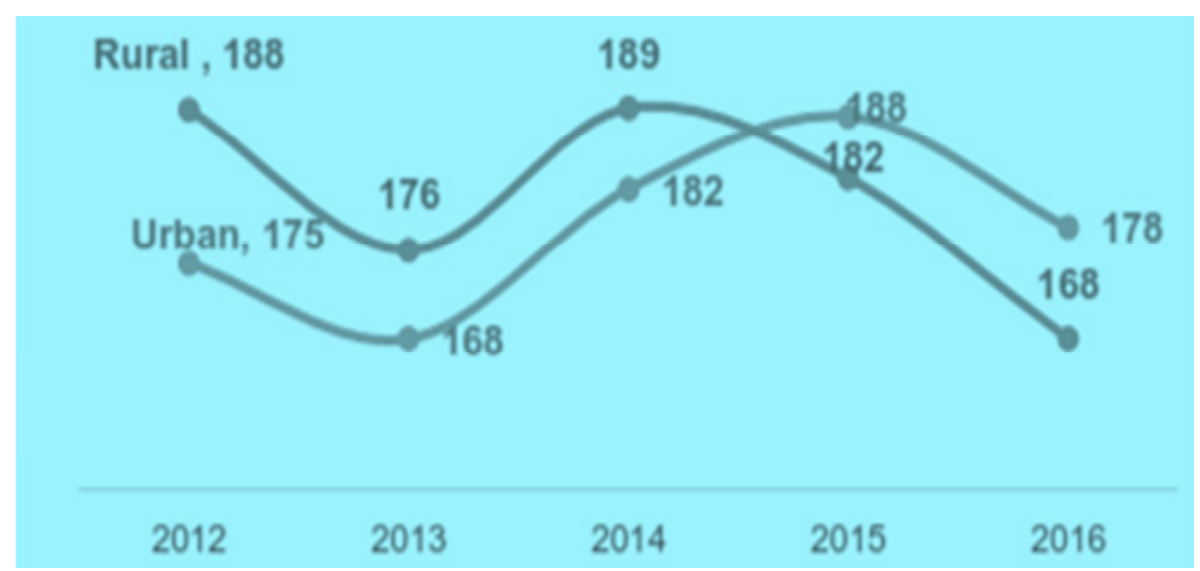

Figure 1. Comparison of trends in consumption of fruits and vegetables per capita a day Period of 2012 to 2016 (in grams) 
Figure 2 shows that the enthusiasm of farmers to cultivate this type of vegetable experiences sluggish conditions which will have result in an imbalance in supply and demand for long beans while the community interest for consuming this type of vegetable is quite strong. In such conditions, the end-consumer price of long beans will be significantly affected, resulting in a very sharp marketing margin yet weaker bargaining position for farmers.

The long bean production centers in Jember Regency are distributed in 21 out of 31 existing districts. One of the sub-districts in Jember Regency that has the largest harvested area and long bean production in 2016 is the District of Ambulu, $141 \mathrm{Ha}$ and $5462 \mathrm{Kw}$, respectively. However, the level of productivity is the lowest compared to other districts, which is $38.74 \mathrm{kw} /$ ha or below the dyke sub-district (38.83 kw/ha) and the biggest productivity is in Puger sub-district at 83.73 kw/ha (Table 1 and Figure 3) (BPS KabupatenJember, 2017).

The low price of long beans in Ambulu and the whole Jember has implications for various marketing dimensions. Farmer's share will below because of the low price of the product at the farm level. Consequently, the subsequent marketing process will run inefficiently in various patterns of marketing channels due to very high marketing margins. High marketing margins are not equivalent to high marketing profits for the marketing institutions involved. If the marketing costs incurred are high, the marketing profit will be low even though the margins are high. Even worse, the end consumers will need to pay all marketing costs. On the other hand, farmers as producers actually receive prices that are not comparable with the production costs incurred during the production process. Therefore, the objectives of this study were formulated as follows: to know the performance of long bean marketing channels formed in vegetable trading, analyze the marketing value of long beans contributing to inefficient marketing of vegetables, and analyze the elasticity of long bean transmission prices in Ambulu, Jember Regency. The scope of this research includes a study of the pattern of marketing channels, marketing efficiency and the price elasticity of transmission from long bean marketing in the sub-district of Ambulu, Jember Regency.

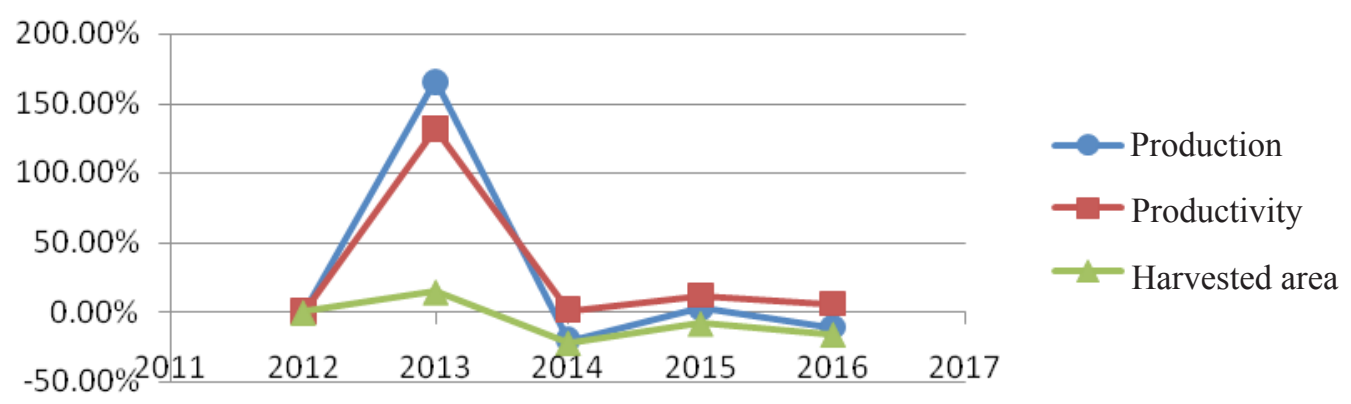

Figure 2. Development of harvested area, production and productivity of long beans in Jember 2012-2016 (Statistics Indonesia, 2017)

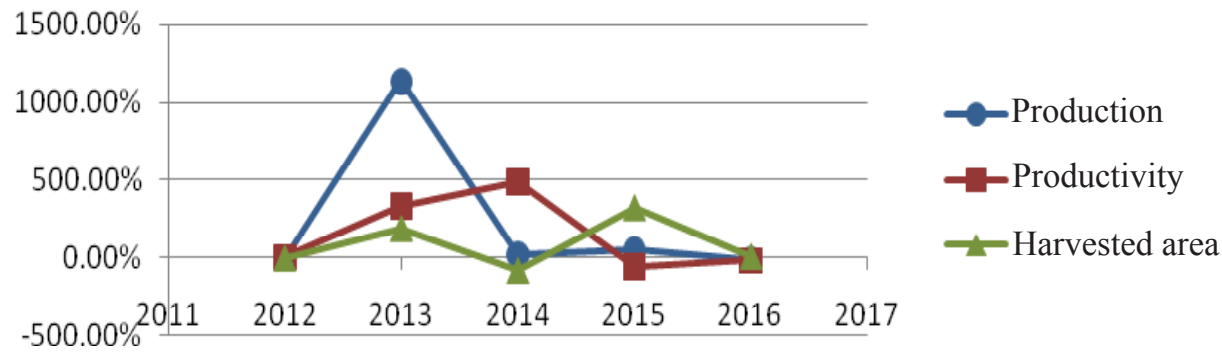

Figure 3. Development of harvested area, production and productivity of long beans in Ambulu District 2012-2016 (Statistics Indonesia, 2017) 
Table 1. Harvested area, production, and productivity of long beans in Ambulu District in 2012-2016

\begin{tabular}{ccccccc}
\hline \multirow{2}{*}{ Years } & \multicolumn{2}{c}{ Harvested Area } & \multicolumn{2}{c}{ Production } & \multicolumn{2}{c}{ Productivity } \\
\cline { 2 - 6 } & Amount ( ha) & Growth (\%) & Amount ( ton) & Growth (\%) & Amount (tons/ha) & Growth (\%) \\
\hline 2012 & 49 & - & 265 & - & 5.41 & - \\
2013 & 142 & $189.80 \%$ & 3.286 & $1140.00 \%$ & 23.14 & $327.89 \%$ \\
2014 & 30 & $-78.87 \%$ & 4.076 & $24.04 \%$ & 135.87 & $487.13 \%$ \\
2015 & 127 & $323.33 \%$ & 6.290 & $54.32 \%$ & 49.53 & $-63.55 \%$ \\
2016 & 141 & $11.02 \%$ & 5.462 & $-13.16 \%$ & 38.74 & $-21.79 \%$ \\
Average & 98 & 0.89 & 3876 & 2.41 & 50.54 & 1.46 \\
\hline
\end{tabular}

\section{METHODS}

This research was conducted in March - October 2019 and carried out in several villages within Ambulu District area, Jember Regency by purposive sampling. This site was chosen by considering that Ambuluhas the highest harvest and production area in Jember Regency, but the lowest productivity. While on the other hand market access to long bean production at the research location is quite easy although its production price is very low. The market investigated in the study are is located at five markets in the District of Ambulu including the wholesale market at the center of the subdistrict.

This type of research is used quantitative and qualitative descriptive research which aims to describe a phenomenon systematically, factually and accurately about facts, traits and relationships within the phenomenon occurring simultaneously (Whitney, 1960 in Nazir, 1985). Meanwhile, the method used in this study is a survey method, and a descriptive continuity method with the Snowballing Sampling technique (Nazir, 1985). This method was preferred to see the extent of the condition of long bean farmers objectively. While the use of the snowballing sampling method was intended because respondents' characteristics had been determined, that they had to come from elements of marketing institutions such as collectors and retailers with a balanced amount in order to study marketing distribution channels from farmers to end consumers.

Sampling of long bean farmers is done by the method of proportioned random sampling means that sampling is carried out proportionally randomly to long bean farmers from each village in Ambulu. In order to obtain a representative sample from the population, every subject in the population must have the same opportunity to become a sample. The formula used to measure the sample was the Slovin's formula in Umar (2004). Upon calculating the population using the formula, there obtained 72 farmers as samples taken from each village, with the following details: 27 samples from Sumberejo Village, 21 samples from Andongrejo Village, and 24 samples from Sabrang Village.

Meanwhile, the sampling technique for the marketing agencies involved was carried out by using snowballing sampling techniques at the locations of long bean farmers, village markets, sub-districts to wholesale markets. The number of samples of marketing agencies is determined proportionally according to the needs of 16 people. Furthermore, the data to be collected in the study included primary and secondary data. Primary data obtained from long bean farmers, traders (marketing agencies), and end consumers were collected through a combination of several complementary data collection techniques including: in-depth interviews and observations.

In order to answer the first research problem, a qualitative descriptive analysis was used to determine the pattern of long bean marketing channels formed in Jember Regency (Singarimbun, 1987). In the second research problem, an analysis of marketing margins can also be calculated using the following mathematical formula (Masyrofi, 1994):

$\mathrm{m} \mathrm{n}$

$$
\underset{i=1}{\mathrm{MP}}=\sum \sum \mathrm{C}_{\mathrm{ij}}+\sum \pi_{\mathrm{j}}
$$

Descriptors: M (Marketing margin); Cij (marketing costs to carry out the i-th marketing function by the institution); marketing to $\mathrm{j}$ ); $\pi \mathrm{j}$ (profit obtained by the $\mathrm{j}$-th marketing institution); $\mathrm{m}$ (Number of types of marketing costs); $\mathrm{n}$ (Number of marketing institutions) 
Rationality was determined by comparing the level of profit with the costs incurred by marketing institutions during the process of buying and selling long beans (Ratio $=\pi /$ Sbi). Furthermore, Gultom (1996) in Putra Bisuk (2009) also states that in general a trading system for (part of) agricultural products can be said to be efficient if the shareholder margin is above $50 \%$. The part of the price received by the farmer (farmer share) is a comparison of the price received by the farmer with prices at the level of the marketing institution expressed as a percentage. Farmer's share referred to is formulated as follows: $\mathrm{Fs}=\mathrm{Pf} / \operatorname{Pr} \times 100 \%$, where $\mathrm{FS}=$ farmer's share, $\operatorname{Pr}=$ price at retail level, and $\mathrm{Pf}=$ price at farmer level.

To answer the third problem regarding transmission price elasticity $(\eta)$ where the definition is the percentage change in retail prices to that in price at the producer farm level, the following formula was used to calculate (Masyoefi, 1994):

$$
\eta=. \frac{\operatorname{Pf}}{b P r} .
$$

Therefore the decision criteria are as follows (Azzaino, 1982):

a) If $\eta=1$, a price change of $1 \%$ at the retail level will result in a price change of $1 \%$ at the farm level and is a perfectly competitive market, and the trading system that is already efficient,

b) If $\eta<1$, then If the transmission elasticity of the price is less than one $(\eta<1)$ it can be interpreted that a price change of $1 \%$ at the retail level will result in a price change of less than $1 \%$ at the farm level and the market shape leads to Monopsony and marketing is inefficient, and

c) If $\eta>1$, means that if the price transmission elasticity is greater than one $(\eta>1)$, then a price change of $1 \%$ at the retail level will result in price changes greater than $1 \%$ at the farm level and the form of the market leads to Monopoly to Oligopoly or marketing is not efficient yet.

Hypothesis

1) It is assumed that several patterns of long bean marketing channels at the research location are efficient

2) It is assumed that the elasticity of the marketing price transmission of string long beans at the research location is inefficient

The basis for the formulation of this hypothesis is that the price changes at the farm level are lower than at the consumer level.

The ongoing marketing of long bean commodity at the research location has implications for the established marketing channel patterns, the level of marketing efficiency for each marketing pattern, and how the price of long beans at the farmer level changes at the consumer level. This phenomenon will provide an overview of how much profit is received by farmers in the process of marketing the commodity, and what price consumers must pay for the transfer of ownership of goods from farmers, and how rational is the level of profit on the costs incurred by each marketing agency. Figure 4 is a schematic of the framework for this research.

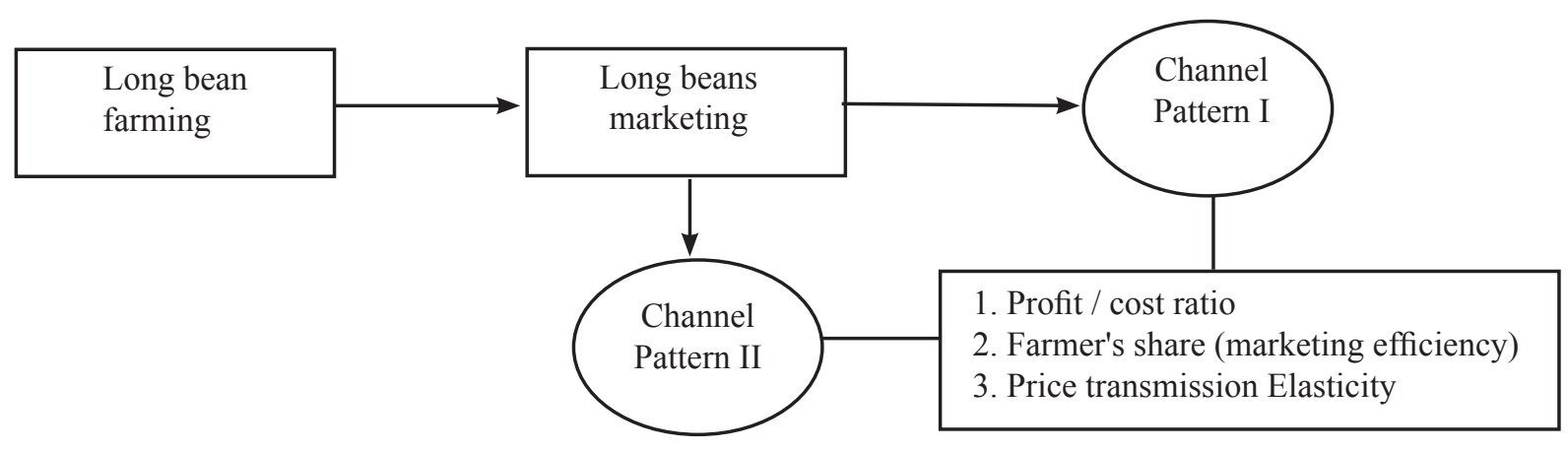

Figure 4. Long bean marketing research framework 


\section{RESULTS}

\section{Long Bean Marketing Channel Pattern}

The length of a marketing channel will be determined by the number of intermediaries (middleman) traversed by goods and services. A long distribution channel will cause more chains to participate in marketing activities, leading to the broad reach of the final consumer, yet the price is relatively expensive. Conversely, a relatively short distribution channel might be less effective for dissemination. Yet, due to shorter marketing chain, production costs can be reduced significantly, resulting in lower consumers' prices. In other words, the length of marketing channels will determine the level of marketing efficiency.

In the discussion of long bean commodity marketing channel patterns in this research area, it can be explained that the marketing channel pattern is quite simple, starting from the farmer to the end consumer, forming two channel patterns, namely the second and first level channels. The two long bean marketing channel patterns can be described as follows (Figure 5):

1. Long Bean Farmers $(37,50 \%) \rightarrow$ Collectors $\rightarrow$ Retailers $\rightarrow$ Consumers

2. Long Bean Farmers $(62,50 \%) \rightarrow$ Retailers $\rightarrow$ Consumers

Figure 5. One-level and two-level patterns of Long beans Marketing Channel in Ambulu District, Jember Regency

The study revealed two kinds of marketing channel patterns of long bean marketing, namely one level and two- level marketing patterns. In theory, the longer the marketing channel, the less efficient marketing will be, and vice versa. The results of this study are in line with the results of Arvianti and Mubaidi's research in 2012 who revealed two patterns of the long bean marketing channels in Kuripan Village, Babat Subdistrict, Lamongan Regency, marketing channel I involves farmers, village/middleman traders and large markets, while marketing channel II involves farmers, district-level collectors and large market traders. The marketing functions carried out are the exchange function consisting of the purchase and sales functions, physical functions consisting of storage and transportation functions, and facility functions, namely market information.

\section{Marketing Margin}

\section{First Channel Pattern (Two-Level Channels)}

This marketing channel pattern is classified as efficient because farmer's share value is $50.37 \%$ or higher than $50 \%$ although at the same time, the lowest efficiency level is achieved. Traders receive a marketing profitbenefit ratio of more than 10 and retailers reach a ratio of 9. In other words, the level of fairness is still not proportional because retailers incur higher marketing costs compared to merchant collectors. When compared with the results of Yasrika's study (2018) in the Manyak Payed District of Aceh Tamiang, the farmer share on this two-level channel is actually much higher, reaching $66.08 \%$. The marketing margin in Yasrika's research (2018) was lower (IDR2,250.00 per kg) compared to the marketing margin in this study (IDR3,383 per kg). Therefore, it is very natural that the farmer share of the first channel pattern of this study $(50.37 \%)$ is much lower compared to that of Yasrika's (66.08\%) (2018). Likewise, marketing efficiency in this study (50.37\%) is much lower compared to the results obtained by Megasari, Yurisinthae, and Yusra (2018) taking place in Rasau Jaya I West Kalimantan (75\%). Because the price of long beans at the retail level in the research of Megasari et al. (2018) is IDR8,000 per kg, but the price at the farm level reaches IDR7,000 per $\mathrm{kg}$ in the same channel pattern. Therefore, the marketing margin is lower (IDR1,000 per $\mathrm{kg}$ ) compared to the results of this study and Yasrika (2018).

\section{Second Channel Pattern (One-Level Channel)}

Table 4 below shows that this marketing channel pattern has a high level of efficiency when compared to the first channel pattern (two-level channel) above. This is indicated by the Farmer's share value in this channel pattern reaching $78.57 \%$. Retailers receive a level of profit-marketing ratio that is greater than 10 and higher than the retailer's profit-cost ratio in the two-level channel above (9.27) (Table 3). If viewed from the aspect of prices at the producer level and consumer level prices, the difference between the two is not significantly high, causing the marketing margins to be relatively low (IDR1,500 per $\mathrm{kg}$ ) even lower than the first channel pattern.

The marketing margins of the results of this study are even smaller than those of Megasari, et.al (2018) with the same channel pattern (one level channel), where the 
price of long beans at the farm level reaches IDR6,000 per kg and prices at the retail level reach IDR8,000 per $\mathrm{kg}$ so that the marketing margin is Rp. 2,000 per kg. The level of marketing efficiency in this study can be shown by the value of the farmer's share $(78.57 \%)$ and is higher than those revealed by Megasari et. al. (2018) (75\%). This may be caused by marketing costs per $\mathrm{kg}$ incurred by retailers in this study which are lower than the results from Megarsariet. al (2018), so this difference in marketing margins causes differences in the level of efficiency.

\section{Compilation of Marketing Margins and Price Transmission Elasticity}

In general, through long bean marketing channel patterns revealed the study can also be seen the magnitude of the price transmission elasticity $(\eta) . \eta$ is meant the percentage change in retail price against the percentage change in price at the producer farm level or the ratio of changes in the value of consumer prices to changes in prices at producer level. This price transmission analysis provides an illustration of how the prices paid by end consumers are transmitted to producers. To see the relationship of price elasticity at the producer level and consumer level, it can be seen the elasticity of price transmission that is the relative change from retail prices to the change in relative prices at producer level (Azzaino, 1982). Price transmission elasticity can be formulated as follows (George and King, 1971):

$$
\eta=\mathrm{dPr} / \mathrm{dPf} . \operatorname{Pf} / \operatorname{Pr}
$$

where: $\eta=$ price transmission elasticity, $\operatorname{Pr}=$ prices at the consumer level, $\mathrm{Pf}=$ prices at the producer farm level, $\mathrm{d} \operatorname{Pr}=$ price changes at the consumer level, and $\mathrm{d}$ $\mathrm{Pf}=$ price changes at the producer level.

Before analyzing the elasticity of price transmission, it is important to find the regression coefficient (b) of the retail price variable (pr), because prices have a linear relationship, where $\mathrm{Pf}$ is a function of $\mathrm{Pr}$ which is mathematically formulated as: $\mathrm{Pf}=\mathrm{a}+\mathrm{b}$ Pr. Price elasticity can also be sought by using the logarithm of the function (Azzaino, 1982): $\mathrm{Pf}=\mathrm{a}+\operatorname{Pr} \mathrm{n}$, then $\ln \mathrm{Pf}$ $=\ln \mathrm{a}+\mathrm{n} \ln$ Pr. The results of the regression analysis through the mathematical model approach resulted in a regression coefficient value on the Pr variable of 0.419 as shown in Table 5.

Table 3. Analysis of long bean marketing margins in the pattern of the first marketing channel (two-level channel) in Ambulu District, Jember Regency

\begin{tabular}{|c|c|c|c|c|c|c|}
\hline $\begin{array}{l}\text { Types of Long } \\
\text { Bean Marketing } \\
\text { Institutions }\end{array}$ & $\begin{array}{c}\text { purchase price } \\
/ \mathrm{Kg}\end{array}$ & $\begin{array}{c}\text { Selling price / } \\
\mathrm{Kg}\end{array}$ & $\begin{array}{c}\text { Marketing } \\
\text { Cost } / \mathrm{Kg}\end{array}$ & Profit $/ \mathrm{Kg}$ & $\begin{array}{c}\text { farmer's share } \\
{[(\mathrm{Pf} / \mathrm{Pr}) \mathrm{x}} \\
100 \%]\end{array}$ & $\begin{array}{l}\text { Ratio Profit- } \\
\text { Cost }\end{array}$ \\
\hline 2 & 3 & 4 & 5 & 6 & 7 & 8 \\
\hline \multicolumn{2}{|c|}{ Average Farmer Prices(Pf) } & 3,433 & & & 50.37 & \\
\hline Colector & 3,433 & 5,500 & 106 & 1,961 & & 18.56 \\
\hline Retailer & 5,500 & 6,817 & 128 & 1,188 & & 9.27 \\
\hline \multicolumn{3}{|c|}{ Share Margin of Marketing (\%) } & 3.43 & 46.20 & & \\
\hline \multicolumn{2}{|c|}{ Marketing Margin } & 3,383 & Share $\mathrm{N}$ & Amount & 100.00 & \\
\hline
\end{tabular}

Table 4. Analysis of long bean marketing margins in the pattern of the second marketing channel in Ambulu District, Jember Regency

\begin{tabular}{lcccccc}
\hline $\begin{array}{l}\text { Types of Long } \\
\text { Bean Marketing } \\
\text { Institutions }\end{array}$ & $\begin{array}{c}\text { purchase price } \\
/ \mathrm{Kg}\end{array}$ & $\begin{array}{c}\text { Selling price / } \\
\mathrm{Kg}\end{array}$ & $\begin{array}{c}\text { Marketing } \\
\text { Cost/Kg }\end{array}$ & Profit/Kg & $\begin{array}{c}\text { farmer's share } \\
{\left[\begin{array}{l}(\mathrm{Pf} / \mathrm{Pr}) \mathrm{x} \\
100 \%]\end{array}\right.}\end{array}$ & $\begin{array}{c}\text { Ratio Profit- } \\
\text { Cost }\end{array}$ \\
\hline 2 & 3 & 4 & 5 & 6 & 7 & 8 \\
\hline Average Prices Farmer (Pf) & 5,500 & & & 78.57 & \\
Retailer & 5,500 & 7,000 & 128 & 1,372 & & 10.70 \\
Share Margin of Marketing (\%) & & 1.83 & 19.60 & & \\
Marketing Margin & 1,500 & \multicolumn{2}{l}{ Share Margin Amount } & 100.00 & \\
\hline
\end{tabular}


Table 5 . Results of regression analysis of Pf variables against Pr in the long bean marketing channel in Ambulu District, Jember Regency

\begin{tabular}{llccccc}
\hline Model & & \multicolumn{2}{c}{ Unstandardized Coefficients } & Standardized Coefficients & $\mathrm{t}$ & \multirow{2}{*}{ Sig. } \\
\cline { 3 - 5 } & & $\mathrm{B}$ & Std. Error & Beta & & \\
\hline 1 & (Constant) & -2.415 & 1.303 & & -1.853 & .094 \\
& Pr & .419 & .150 & .663 & 2.798 & .019 \\
\hline
\end{tabular}

Table 6 explains that in general long bean marketing channel patterns in the study area are running less efficiently, because the farmer's share value is less than $50 \%$. Retailers achieve higher levels of efficiency compared to merchant collectors, this is because in addition to the more limited marketing functions, they can also offer the best price to the end consumers. This condition has placed farmers as a victim by this marketing system because they have to take an unfair price. The next victims are consumers who have to pay irrational prices.

In line with the value of this price transmission elasticity, it is expected that information will be obtained which will later be used to improve the bargaining position of farmers. The results of the study as presented in Table 6 above also revealed that the magnitude of price transmission elasticity $(\mathrm{Et})=1.17$, which means that if the price change of long beans at the end consumer level by $1 \%$, will result in price changes at the farm level by $1.17 \%$ and the shape of the market structure leads to imperfect competition (Oligopoly). This means that the marketing system formed in the pattern of long bean marketing channels in this research area is said to be running almost efficiently (Azzaino, 1982). Therefore, the bargaining position of long bean producer farmers in the study area is still relatively worrying.

This condition remains a problem for price stability in the market mainly at the farm level. Because if price is increasing at the consumer level of by $1 \%$, the farmers are still benefiting because the price increase is still greater $(0.17 \%)$ than that at the consumer level. On the contrary, if there is a decrease in prices at the end consumer level by $1 \%$, prices at the farm level will also decrease, even lower than those at the consumer level of $0.17 \%$. This will be detrimental to farmers in the long run if this condition is left to run as it is today.

\section{Managerial Implications}

Based on the results of the discussion, the pattern of marketing channels can be intervened by the government through market protection. This effort is expected to make prices received by farmers more feasible and rational, to appreciate their sacrifice of long bean farming activities. If there is no market intervention, the marketing agencies involved will continue to maintain their current treatments, where they can determine prices according to their wishes but ignore prices at the farm level.

\section{CONCLUSIONS AND RECOMMENDATIONS}

\section{Conclusions}

The pattern of long bean marketing channels formed by two- channel patterns, namely the second and first level channels as follows: Farmer --- Collector --- Retailer --- Consumer, and Farmer --- Retailer --- Consumer, 2) Pattern of marketing channel first (second level) has a marketing margin of Rp3IDR3.383 per $\mathrm{kg}$ with a profit-marketing ratio of middlemen and retailers disproportionate (less than fair/rational) with the amount of 18,56 and 9,27, respectively. The second marketing channel pattern (level one) has a marketing margin of Rp IDR1.500 per kg with the profit-cost ratio received by retailers reaching 10,70 (relatively proportional/ rational), and 3) the pattern of marketing channels that are built generally has transmission elasticity a price of $\eta=1,17(\eta>1)$ and the shape of the market structure leads to an imperfect competition market (Monopoly to Oligopoly) and the bargaining position of long bean farmers is relatively worrying.

\section{Recommendations}

Following the findings of the study, it is recommended that long bean farmers sell their products in a onelevel channel pattern and the government periodically provide market information about price dynamics and total market demand for long bean commodities to ensure price stability. 
Table 6. Long Bean Marketing Channel Patterns in Ambulu District, Jember Regency (Results of the Compilation of Two Channel Patterns)

\begin{tabular}{|c|c|c|c|c|c|c|c|}
\hline $\begin{array}{l}\text { Types of Long } \\
\text { Bean Marketing } \\
\text { Institutions }\end{array}$ & $\begin{array}{l}\text { purchase } \\
\text { price } / \mathrm{Kg}\end{array}$ & $\begin{array}{l}\text { Selling price } \\
\text { /Kg }\end{array}$ & $\begin{array}{c}\text { Marketing } \\
\text { Cost/Kg }\end{array}$ & Profit /Kg & $\begin{array}{l}\text { Farmer's } \\
\text { Share }(\%)\end{array}$ & $\begin{array}{c}\text { Transmission } \\
\text { Price } \\
\text { Elasticity }(\eta= \\
(1 / b) \times(P f / P r)\end{array}$ & $\begin{array}{c}\text { Marketing } \\
\text { Efficiency [ } \\
\text { (Marketing } \\
\text { Cost : Sales } \\
\text { Price) x } 100 \%]\end{array}$ \\
\hline \multicolumn{2}{|c|}{ Average Prices Farmer (Pf) } & 3,433 & & 49.05 & & & \\
\hline Collectors & 2,800 & 3,200 & 170 & 230 & & 0.419 & 5.31 \\
\hline Collectors & 3,200 & 4,000 & 143 & 657 & & & 3.58 \\
\hline Collectors & 3,000 & 3,500 & 143 & 357 & & & 4.09 \\
\hline Collectors & 3,000 & 4,000 & 143 & 857 & & & 3.58 \\
\hline Collectors & 3,000 & 4,300 & 170 & 1,130 & & & 4.33 \\
\hline Collectors & 3,500 & 4,500 & 195 & 805 & & & 1.45 \\
\hline Collectors & 4,000 & 10,000 & 145 & 5,855 & & & 1.50 \\
\hline Collectors & 4,000 & 10,000 & 150 & 5,850 & & & 1.88 \\
\hline Collectors & 4,000 & 8,000 & 150 & 3,850 & & & 2.42 \\
\hline Collectors & 4,000 & 6,000 & 145 & 1,855 & & & 3.75 \\
\hline Collectors & 3,000 & 4,000 & 150 & 850 & & & 3.33 \\
\hline Collectors & 3,700 & 4,500 & 150 & 650 & & & 3.26 \\
\hline $\begin{array}{l}\text { Average (IDR/ } \\
\mathrm{Kg})\end{array}$ & 3,433 & 5,500 & 155 & 1,912 & & & 3.26 \\
\hline Retailers & 5,000 & 6,000 & 138 & 862 & & & 2.30 \\
\hline Retailers & 7,500 & 9,000 & 125 & 1,375 & & & 1.39 \\
\hline Retailers & 4,750 & 6,500 & 104 & 1,646 & & & 1.6 \\
\hline Retailers & 4,750 & 6,500 & 146 & 1,604 & & & 2.25 \\
\hline $\begin{array}{l}\text { Average (IDR/ } \\
\mathrm{Kg})\end{array}$ & 5,500 & 7,000 & 128 & 1,372 & & & 1.88 \\
\hline $\begin{array}{l}\text { Marketing } \\
\text { Margin (IDR) }\end{array}$ & 3,567 & & Margin Amo & & 100.00 & 1.17 & \\
\hline
\end{tabular}

\section{ACKNOWLEDGMENTS}

The authors would like to express their gratitude to the Institute of Research and Community Service at Universitas Muhammadiyah Jember for their financial and guidance support that contributes to the success of this research conduct, thus this article can be completed.

\section{REFERENCES}

Adityas AR, Hasyim AI, Affandi MI. 2018. Analysis of farm revenue and marketing of leading vegetables in the agropolitan area of tanggamus regency. Jurnal Ilmu Ilmu Agribisnis: Journal of Agribusiness Science 6 (01): 41 - 48. https://doi. org/10.23960/jiia.v6i1.41-48.

Anto A. 2013. Long Bean Cultivation Technology. Central Kalimantan: BPTP Agricultural Extension.

Arvianti AR, Mubaidi. 2012. The influence of the marketing system on the income of farmers in Kuripan Village, Babat District, Lamongan Regency. Buana Science 12 (1): 1-6.

Azziano Z. 1982. Introduction to Agricultural Commerce. Agriculture department. Agricultural Socio-Economic Sciences. IPB: Bogor.

Bisuk P. 2009. Analysis of Trade Management and Transmission Elasticity of International CPO Prices on Oil Palm FFB (Fresh Fruit Bunches) Prices (Case Study: Mananti Village, Sosa Subdistrict, PadangLawas Regency). [Essay]. Field. p. 76.

BPS Jember Regency. 2017. Jember Regency in Numbers. https://jemberkab.bps.go.id/ subject/55/horticulture.html. [29 Jan 2019].

Indonesian Food Security Monitoring Bulletin. 2017. Special Focus: Trends in fruit and vegetable consumption and production Volume 8, November 2017. https://docs.wfp.org/api/ documents/WFP-0000024091. [ 25 Jan 2019].

George PS, King GA. 1971. Consumer Demand Food Commodities in The United States with Projection 
for 1980. Giani: Foundation Mongograp.

Hasyim A. 2012. Agricultural Management. Bandar Lampung: Lampung University.

Husein U. 2004, Research Methods for Thesis and Business Thesis, 6th Cet, Jakarta: PT Raja GrafindoPersada.

Kominfio Jatim. 2015. Demand increases, horticultural production rises 10 percent. http://kominfo. jatimprov.go.id/read/umum/44793.[ 26 January 2019].

Kusmargana JH. 2018. Long bean prices drop, farmers are reluctant to sell. https://www.cendananews. com. [28 Jan 2018].

Maspur and JS. 2008. Competitivenessanalysis of several types of vegetables in rice fields (case study in AmbuluSubdistrict, Jember Regency, East Java Province). http://digilib.unmuhjember. ac.id/files/disk1/2/umj-1x-maspurdans-65-1-9. analis-h.pdf. [27 Jan 2018].

Masyrofi. 1994. Marketing of Agricultural Products. Malang: Diktat Lecture - Department of Social Economics, Faculty of Agriculture, University of Brawijaya. Poor.
Megasari LY, Yurisinthae E, Yusra AHA. 2018. Analysis of peanut marketing slides in Rasau Jaya I West Kalimantan. Journal of Agriculture students of Tanjungpura University 7(3): 55 - 66.

Nazir. 1985. Research Methods. Jakarta: Ghalia Indonesia.

Pratiwi D, Hasyim AI, Affandi MI. 2016. Financial analysis and development strategy for honey pineapple in East Lampung Regency. Jurnal Ilmu Ilmu Agribisnis: Journal of Agribusiness Science 4 (1): 8-14.

Rahayu. 2007, Contemporary Marketing Management Questions and Answers. Jakarta: Havarindo Publisher.

Singarimbun, Sofian E. 1987. Survey Research Methods. Jakarta: LP3ES.

Wati AM. 2018. Cultivating long beans. http://eprints. umm.ac.id/38036/2/. [ 25 Jan 2019].

Yasrika K. 2018. Efficiency of long beans marketing in manyakpayed, aceh tamiang regency. ocean university agribusiness study program. https:// etd.unsam.ac.id/detail.php?id=162. Accessed on [25 Nov 2019]. 